\title{
Bariery rozwoju przedsiębiorczości lokalnej w powiecie krośnieńskim i brzozowskim
}

\author{
Barriers to the Development of Local Entrepreneurship \\ in Krosno and Brzozów Districts (Poland)
}

Streszczenie: $\mathrm{W}$ artykule przedstawiono bariery ograniczające przedsiębiorczość lokalną w powiecie krośnieńskim i powiecie brzozowskim. Mikroprzedsiębiorstwa w tym regionie to bardzo ważny element gospodarki, zwłaszcza dla gospodarki lokalnej. Mikroprzedsiębiorczość pozwala budować trwałe fundamenty wzrostu gospodarczego regionu. Przedsiębiorstwa zatrudniające mniej niż 10 pracowników stanowią nieco ponad 95\% wszystkich przedsiębiorstw regionu. Dzięki nim w powiecie krośnieńskim i brzozowskim tworzone są nowe miejsca pracy, co z kolei przekłada się na spadek bezrobocia. $\mathrm{W}$ realiach gospodarki rynkowej okazuje się, że lokalne przedsiębiorstwa napotykają szereg barier, które powodują ograniczenie ich rozwoju. Według badanych przedsiębiorców z powiatu brzozowskiego i krośnieńskiego podstawowymi barierami rozwoju przedsiębiorczości lokalnej są: wysokie składki ZUS, wysokie podatki lokalne, liczne wymagania formalno-prawne i procedury administracyjne, brak działań promujących lokalną gospodarkę, brak wykwalifikowanych pracowników oraz niska siła nabywcza mieszkańców. Nowo proponowane działania rządu mają na celu poprawę sytuacji przedsiębiorców.

\begin{abstract}
The article presents barriers which limit the local entrepreneurship in the Krosno and Brzozów districts (Poland) on the basis of the research conducted. Micro-enterprises in this region are a very important part of the economy and local economy in particular. Micro-entrepreneurship allows to build lasting foundations for the economic growth of the region. Enterprises of less than 10 employees actually make up over $95 \%$ of all enterprises in the region. Thanks to them, new job possibilities are created in the Krosno and Brzozów districts, thus decreasing unemployment. In market economy conditions, it turns out that local enterprises face a number of barriers which halt their development. According to the entrepreneurs surveyed from the Krosno and Brzozów districts, the basic barriers to the development of local entrepreneurship are the following: the amount of ZUS contributions, the amount of local tax charges, numerous formal and legal requirements and administrative procedures, no actions promoting the local economy, lack of qualified employees and low purchasing power of residents. The newly proposed actions of the government are to improve the situation of entrepreneurs.
\end{abstract}


Słowa kluczowe: bariery rozwoju; lokalna przedsiębiorczość; mikroprzedsiębiorstwa; powiat brzozowski; powiat krośnieński

Key words: barriers to the development; Brzozów district; Krosno district; local entrepreneurship

Otrzymano: 25 października 2018

Received: 25 October 2018

Zaakceptowano: 27 lutego 2019

Accepted: 27 February 2019

\section{Sugerowana cytacja/Suggested citation:}

Suchodolski, M. (2019). Bariery rozwoju przedsiębiorczości lokalnej w powiecie krośnieńskim i brzozowskim. Przedsiębiorczość - Edukacja [Entrepreneurship - Education], 15(1), 205-213. doi: $10.24917 / 20833296.151 .15$

\section{Wstęp}

Przedsiębiorczość lokalna odgrywa istotną rolę w rozwoju polskiej gospodarki. Wspieranie jej przyczynia się w konsekwencji do poprawy poziomu i jakości życia mieszkańców.

Rozwój przedsiębiorczości lokalnej zależy od czynników egzogenicznych i endogenicznych. Czynniki zewnętrzne mają charakter obiektywny i władze lokalne często nie mają na nie większego wpływu. Wiele z nich wynika z procesów globalizacji, konkurencji wewnątrzkrajowej i międzynarodowej oraz polityki gospodarczej państwa (Makieła, 2008). Spośród najważniejszych czynników egzogenicznych wpływających na rozwój przedsiębiorczości lokalnej należy wymienić politykę społeczną i gospodarczą, jakość i stabilność stanowionego prawa, dotacje oraz poziom rozwoju społeczno-gospodarczego. Niebagatelne znaczenie w procesie aktywizacji gospodarczej mają powiązania infrastrukturalne (autostrady, drogi ekspresowe, kolej), instytucje finansowe (dostępność do kredytów), administracyjne oraz decyzje podejmowane przez organy władzy centralnej o prorozwojowej alokacji kapitału. Na czynniki ograniczające przedsiębiorczość lokalną mają wpływ również proporcje w egzogenicznym i endogenicznym zagospodarowaniu popytu lokalnego (Zioło, 2007).

Oprócz wyżej wymienionych uwarunkowań zewnętrznych nie mniej istotną rolę w procesie rozwoju przedsiębiorczości lokalnej odgrywają czynniki endogeniczne. Do najistotniejszych z nich należy zaliczyć: kapitał ludzki i społeczny, kulturę przedsiębiorczości, przychylność władz samorządowych, mentalność mieszkańców, infrastrukturę techniczną, infrastrukturę transportową oraz plany zagospodarowania przestrzennego (Makieła, 2008). Na rozwój przedsiębiorczości lokalnej wpływają również indywidualne cechy osobnicze przedsiębiorców, takie jak: intuicja, determinacja w działaniu, ciekawość, optymizm, zaradność oraz kreatywność (Goszczyńska, Górnik-Durose, 2010).

Wspomniane wyżej uwarunkowania egzogeniczne i endogeniczne mogą być zarówno stymulatorem, jak i barierą rozwoju przedsiębiorczości lokalnej. Dlatego tak ważne jest zidentyfikowanie oraz określenie znaczenia poszczególnych czynników mających wpływ na poziom i jakość przedsiębiorczości lokalnej. Pozwoliłoby to ograniczyć bariery rozwoju i wzmocnić wpływ czynników pozytywnych.

Celem artykułu jest ocena barier rozwoju przedsiębiorczości lokalnej na obszarze powiatu krośnieńskiego i powiatu brzozowskiego. Analizy zawarte w pracy zostały przeprowadzone na podstawie informacji pochodzących z Banku Danych Lokalnych Głównego 
Urzędu Statystycznego oraz badań przeprowadzonych w 2018 r. metodą wywiadu kwestionariuszowego wśród losowo wybranych przedsiębiorców z powiatu krośnieńskiego i brzozowskiego. W niniejszej pracy przyjęto hipotezę badawczą, że istotnymi barierami ograniczającymi rozwój przedsiębiorczości lokalnej są zbyt wysokie składki na ZUS oraz zbyt rozbudowany i skomplikowany system podatkowy.

\section{Pojęcie przedsiębiorczości lokalnej}

Podejmując się określenia barier rozwoju przedsiębiorczości lokalnej, warto najpierw zdefiniować samo pojęcie przedsiębiorczości, które w ostatniej dekadzie jest popularne w mediach, polityce gospodarczej oraz literaturze naukowej. Termin ten jest używany w kontekście psychologicznym, społecznym, organizacyjnym, a najczęściej ekonomicznym (Strojny, Karaś, Kopeć, 2014). Najlepszym dowodem na to, że idea szeroko rozumianej przedsiębiorczości zyskuje na znaczeniu, jest powołanie w styczniu 2018 r. Ministerstwa Przedsiębiorczości i Technologii.

Znaczenie i rolę przedsiębiorczości w rozwoju gospodarki jako jeden z pierwszych zauważył J. Schumpeter. Jego zdaniem przedsiębiorczość przejawia się w poszukiwaniu innowacji w działalności gospodarczej oraz twórczej destrukcji. W tej koncepcji najważniejszą rolę odgrywają przedsiębiorcy, którzy w poszukiwaniu zysku wprowadzają innowacyjne zastosowania, niszcząc dotychczasowy stan równowagi na rynku i ponosząc tym samym ryzyko (Schumpeter, 1960). Według definicji używanej przez polskie Ministerstwo Rozwoju, przedsiębiorczość to skłonność do podejmowania działalności gospodarczej, umiejętność podejmowania ryzyka, a także kreatywność, samorealizacja, elastyczność oraz innowacyjność (Ministerstwo Przedsiębiorczości i Technologii, 2018a). W literaturze ekonomicznej przedsiębiorczość pojawia się najczęściej jako czwarty (obok pracy, ziemi i kapitału) czynnik produkcji.

W przypadku przedsiębiorczości lokalnej oprócz wymienionych wyżej indywidualnych cech osobniczych, szczególną rolę odgrywają władze samorządowe, które tworząc lepsze warunki dla wzrostu aktywności działalności gospodarczej, pobudzają jej rozwój.

Do czynników wpływających na poziom przedsiębiorczości lokalnej można zaliczyć miejscowe tradycje, standard życia i aspiracje mieszkańców, lokalne instytucje otoczenia biznesu, udogodnienia: prawne, administracyjne i podatkowe oraz umiejętność absorpcji środków pomocowych. W tym kontekście dużą rolę odgrywają działania podejmowane przez władze samorządowe (Krajewski, Śliwa, 2004).

\section{Bariery rozwoju przedsiębiorczości lokalnej}

Barierami rozwoju przedsiębiorczości lokalnej możemy nazwać wszystkie te czynniki, które utrudniają lub uniemożliwiają rozwój działalności gospodarczej na danym obszarze. W literaturze przedmiotu można spotkać się z różnymi klasyfikacjami barier rozwoju przedsiębiorczości lokalnej. Według Kamińskiej (2006) wyróżnia się bariery: naturalne, demograficzne, ekonomiczno-techniczne, społeczne i organizacyjno-instytucjonalne (tabela 1$)$.

W innej klasyfikacji barierami ograniczającymi rozwój działalności gospodarczej są: niestabilność i niejasność regulacji prawnych, brak harmonizacji prawa z unijnym porządkiem prawnym, skomplikowane procedury uruchomienia i prowadzenia działalności 
Tabela 1. Klasyfikacja barier ograniczających rozwój indywidualnej działalności gospodarczej

\begin{tabular}{|c|c|}
\hline Rodzaj barier & Czynniki główne \\
\hline Naturalne & $\begin{array}{l}\text { - konflikty przestrzenne } \\
\text { - cena przestrzeni }\end{array}$ \\
\hline Demograficzne & $\begin{array}{l}\text { - niskie kwalifikacje kadry samorządowej } \\
\text { - niskie kwalifikacje przedsiębiorców i pracowników } \\
\text { - brak doświadczenia w prowadzeniu własnych firm } \\
\text { - bierna postawa społeczeństwa i władz samorządowych }\end{array}$ \\
\hline Ekonomiczno-techniczne & $\begin{array}{l}\text { - niestabilna sytuacja gospodarcza kraju } \\
\text { - niedobór kapitału } \\
\text { - niski popyt } \\
\text { - nadmierne obciążenia podatkowe } \\
\text { - wysokie koszty prowadzenia działalności gospodarczej } \\
\text { - wadliwa struktura środków trwałych } \\
\text { - przestarzałe technologie wytwarzania }\end{array}$ \\
\hline Społeczne & $\begin{array}{l}\text { - uwarunkowania psychologiczne i społeczne } \\
\text { - nieakceptowanie rozwarstwień społecznych } \\
\text { - niska świadomość ekonomiczna ludności } \\
\text { - brak etosu przedsiębiorcy i ograniczona kultura } \\
\text { przedsiębiorczości }\end{array}$ \\
\hline $\begin{array}{l}\text { Organizacyjno- } \\
\text {-instytucjonalne }\end{array}$ & $\begin{array}{l}\text { - brak długookresowej lokalnej polityki gospodarczej } \\
\text { - niedobór instytucji otoczenia biznesu } \\
\text { - niedostateczny rozwój lokalnego systemu wspierania firm } \\
\text { - niedopasowanie aktów prawnych do nowych warunków } \\
\text { gospodarowania }\end{array}$ \\
\hline
\end{tabular}

Źródło: Kamińska (2006)

gospodarczej, trudny dostęp do zewnętrznych źródeł finansowania, trudności MŚP z poręczeniem kredytów bankowych, ograniczony dostęp do zamówień publicznych, wahania kursów walut, rosnąca konkurencja, ograniczony popyt, nieprzyjazna polityka rządu, nadmierny fiskalizm, skomplikowany system podatkowy, niejasność regulacji podatkowych, ograniczona pomoc publiczna, ograniczony dostęp do informacji, brak informacji gospodarczej, brak informacji o działalności władz publicznych, trudności i duże koszty w dostępie do infrastruktury, niska mobilność rynku pracy oraz brak akceptacji pracy na własny rachunek (Michalczuk, 2009).

W zależności od analizowanego regionu znaczenie wyżej wymienionych barier będzie różne. W literaturze przedmiotu jedną z podstawowych barier rozwoju społecznego i gospodarczego uznaje się stan infrastruktury transportowej. Brak wystarczającej sieci autostrad i dróg szybkiego ruchu oraz niekiedy kiepski stan techniczny dróg krajowych i wojewódzkich wpływa niekorzystnie na konkurencyjność regionu. Nie bez znaczenia jest również dostęp do magistrali kolejowych oraz lotnisk (Makieła, 2008).

$\mathrm{Z}$ badań ankietowych przeprowadzonych wśród przedsiębiorstw z sektora MŚP w 2016 r. przez Ministerstwo Rozwoju wynika, że najważniejszymi barierami rozwoju przedsiębiorczości są: wysokość podatków i opłat przewidzianych prawem, korupcja, warunki lokalowe (wysokość czynszu, zakup lokalu), brak odpowiednich kwalifikacji siły roboczej, koszt siły roboczej, biurokracja, czas oczekiwania na zapłatę od kontrahenta, 
skomplikowane przepisy prawne, konkurencja innych małych i średnich przedsiębiorstw, konkurencja dużych przedsiębiorstw oraz małe obroty. Od wielu lat kluczowym problemem, przed którym stoją polscy przedsiębiorcy, jest wysokość podatków i innych opłat. Jak wynika z raportu Przedsiębiorczość w Polsce 2017 kwestie te są dotkliwe głównie dla mikroprzedsiębiorców - w szczególności tych samozatrudnionych. W tym samym dokumencie zauważono, że obowiązujące przepisy i procedury mają istotny wpływ na prowadzenie działalności gospodarczej. W roku 2016 dużo przedsiębiorców źle oceniło: jakość przepisów i procedur związanych z prawem podatkowym (59\% badanych), sądownictwo gospodarcze (43\%), kontrolę działalności gospodarczej (38\%) i prawo pracy (35\%) (Ministerstwo Przedsiębiorczości i Technologii, 2018a).

\section{Propozycje regulacji prawnych resortu rozwoju}

Od 2015 r. zintensyfikowano działania na rzecz poprawy warunków prawnych prowadzenia przedsiębiorstw. Sytuację polskich przedsiębiorców w kontekście wyżej opisywanych barier w zakładaniu i prowadzeniu działalności gospodarczej ma poprawić Pakiet 100 zmian dla firm oraz Konstytucja biznesu. Jak wynika z informacji podanych przez Ministerstwo Przedsiębiorczości i Technologii, celem Pakietu 100 zmian dla firm jest zniesienie najbardziej uciążliwych przepisów utrudniających prowadzenie biznesu. W jego w skład wchodzą projekty nowelizacji ustaw, których celem jest: poprawa otoczenia prawnego przedsiębiorców, zmiana procedury administracyjnej, ułatwienie dochodzenia wierzytelności, wprowadzenie instytucji przedstawiciela działającego po śmierci przedsiębiorcy, któremu też powierzone zostanie prowadzenie spraw przedsiębiorstwa, skrócenie okresu przechowywania akt pracowniczych oraz ich elektronizacja, wprowadzenie nowej formy prowadzenia działalności - prostej spółki akcyjnej - zmniejszenie obciążeń BHP przy eksploatacji maszyn i urządzeń technicznych do robót ziemnych, budowlanych i drogowych oraz reforma Głównego Urzędu Miar (Ministerstwo Rozwoju, 2018).

Odpowiedzią na opisywane wcześniej problemy związane z prowadzeniem przedsiębiorstwa jest również wejście w życie w kwietniu 2018 r. Konstytucji biznesu. Jest to pakiet ustaw, których celem jest zreformowanie i uproszczenie przepisów dotyczących prowadzenia działalności gospodarczej. Zmiany, które wprowadza Konstytucja biznesu, dotyczą m.in.:

- ułatwień w zakładaniu firmy,

- relacji między przedsiębiorcą a urzędami,

- procedur związanych z zawieszeniem działalności,

- obowiązków związanych z prowadzeniem działalności.

Za najważniejszą ustawę w ramach Konstytucji biznesu uważa się przepisy prawne, które określają najistotniejsze prawa przedsiębiorcy i zasady prowadzenia działalności gospodarczej. Regulacje prawne obejmują również: wprowadzenie zasady „co nie jest prawem zabronione, jest dozwolone”, domniemanie uczciwości przedsiębiorcy, przychylnej interpretacji przepisów, powołanie Rzecznika Małych i Średnich Przedsiębiorstw, wprowadzenie działalności nierejestrowej oraz zwolnienie z płacenia składek ZUS przez sześć miesięcy od dnia założenia firmy (Ministerstwo Przedsiębiorczości i Technologii, 2018b). 
Bariery ograniczające przedsiębiorczość lokalną w powiecie krośnieńskim i brzozowskim

Zarówno dla powiatu krośnieńskiego, jak i dla powiatu brzozowskiego przedsiębiorczość lokalna jest podstawą rozwoju gospodarczego regionu. Zdecydowaną większość podmiotów gospodarczych w 2017 r. stanowiły mikroprzedsiębiorstwa, tj. w powiecie brzozowskim 95,7\%, natomiast w powiecie krośnieńskim 96,3\%. W 2017 r. w sektorach gospodarki powiatu brzozowskiego dominowały podmioty zajmujące się działalnością: budowlaną, handlową, przetwórstwem przemysłowym, transportem oraz opieką zdrowotną i pomocą społeczną, a w powiecie krośnieńskim: działalnością handlową, budowlaną, przetwórstwem przemysłowym, transportem, działalnością profesjonalną oraz opieką zdrowotną i pomocą społeczną. Jak wynika z tabeli 2, w obu powiatach zauważalny jest trend wzrostowy liczby podmiotów gospodarczych.

Tabela 2. Zmiany w liczbie podmiotów gospodarczych w powiecie brzozowskim i powiecie krośnieńskim w latach 2012-2017

\begin{tabular}{|c|c|c|c|c|}
\hline \multirow{2}{*}{ Rok } & \multicolumn{2}{|c|}{ Powiat brzozowski } & \multicolumn{2}{c|}{ Powiat krośnieński } \\
\cline { 2 - 5 } & $\begin{array}{c}\text { liczba podmiotów } \\
\text { gospodarczych }\end{array}$ & $\begin{array}{c}\text { dynamika } \\
\mathbf{2 0 1 2 = 1 0 0 \%}\end{array}$ & $\begin{array}{c}\text { liczba podmiotów } \\
\text { gospodarczych }\end{array}$ & $\begin{array}{c}\text { dynamika } \\
\mathbf{2 0 1 2}=\mathbf{1 0 0 \%}\end{array}$ \\
\hline 2012 & 3021 & 100 & 5819 & 100 \\
\hline 2013 & 3123 & 103 & 5928 & 102 \\
\hline 2014 & 2995 & 99 & 6027 & 104 \\
\hline 2015 & 3037 & 101 & 6107 & 105 \\
\hline 2016 & 3043 & 101 & 6105 & 105 \\
\hline 2017 & 3132 & 104 & 6224 & 107 \\
\hline
\end{tabular}

Źródło: opracowanie własne na podstawie danych GUS (www.stat.gov.pl)

W powiecie brzozowskim w okresie od 2012 r. do 2017 r. liczba przedsiębiorstw zwiększyła się o 4\%, natomiast w powiecie krośnieńskim o 7\%. Większa dynamika zmian liczby podmiotów gospodarczych w powiecie krośnieńskim wynika z większego popytu, dogodniejszej komunikacji drogowej oraz bliskości ważnego ośrodka w regionie, jakim jest miasto Krosno. Na rycinie 1 wyraźnie widać, że w obu analizowanych powiatach dominuje sektor usługowy (w powiecie brzozowskim stanowi on $64,7 \%$, natomiast w powiecie krośnieńskim - 69,4\%).

W obu powiatach przedsiębiorczość lokalna to ważny element wpływający na kondycję gospodarczą regionu oraz na poziom i jakość życia mieszkańców. W tym kontekście ustalenie barier hamujących przedsiębiorczość jest działaniem koniecznym w celu określenia kierunków prowadzących do jej dynamiczniejszego rozwoju.

Aby określić bariery rozwoju przedsiębiorczości lokalnej, przeprowadzono badania. Metodą wywiadu kwestionariuszowego zbadano opinie właścicieli przedsiębiorstw na temat barier funkcjonowania i rozwoju podmiotów gospodarczych w powiecie krośnieńskim i brzozowskim w roku 2018 r. (jeszcze przed wprowadzeniem w życie Pakietu 100 zmian dla firm oraz Konstytucji biznesu). Respondent miał ustosunkować się do określonych barier, określając przy tym ich ważność w skali od 0 do 5 . Badaniem zostało objętych 
Rycina 1. Struktura podmiotów gospodarczych w powiecie krośnieńskim i powiecie brzozowskim w $2017 \mathrm{r}$.

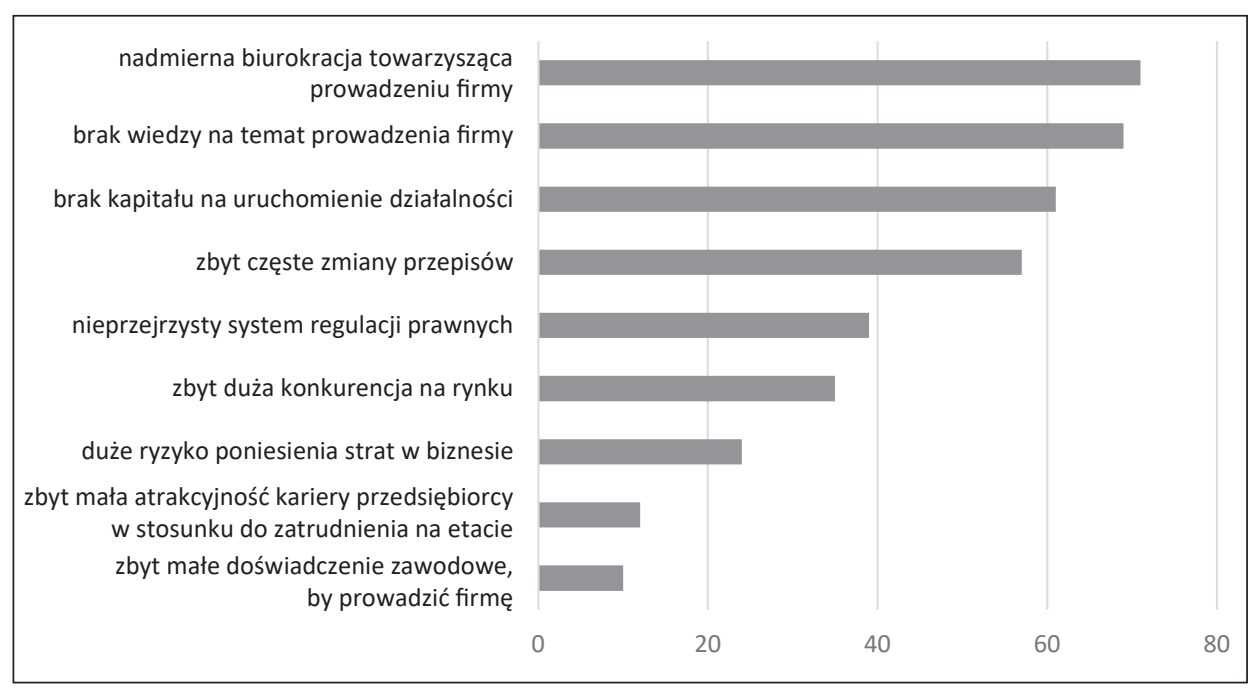

Źródło: opracowanie własne na podstawie danych GUS (www.stat.gov.pl)

60 losowo wybranych przedsiębiorstw z powiatu brzozowskiego i krośnieńskiego. Zestawienie barier ograniczających lub utrudniających przedsiębiorczość lokalną przedstawiono w tabeli 3.

Analizując otrzymane wyniki z obu powiatów, można zaobserwować, że najważniejszymi barierami rozwoju przedsiębiorczości lokalnej (w opinii respondentów) są: zbyt wysokie składki ZUS, wysokie podatki lokalne oraz zbyt rozbudowany i skomplikowany system podatkowy. Otrzymane wyniki w dużej mierze pokrywają się z innymi badaniami, o których była mowa we wcześniejszej części artykułu. Jedną z istotniejszych barier w ocenie badanych przedsiębiorców okazał się brak działań promujących lokalną gospodarkę ze strony lokalnych władz. W obu powiatach porównywalną wartość oceny posiada bariera w postaci braku wykwalifikowanych pracowników. Należy tutaj zaznaczyć, że w dużej mierze dotyczy to branży budowlanej i handlowej. Niedobór pracowników związany jest z emigracją zarobkową, która często wynika z poczucia zbyt niskich wynagrodzeń. Zauważalna jest rozbieżność ocen przedsiębiorców z powiatu brzozowskiego i krośnieńskiego w przypadku takich barier, jak: brak wsparcia informacyjnego w gminie na temat warunków prowadzenia działalności gospodarczej oraz trudności w uzyskaniu i załatwianiu spraw w lokalnych urzędach. W ocenie przedsiębiorców z powiatu brzozowskiego nie są to tak istotne bariery jak dla przedsiębiorców z powiatu krośnieńskiego. Najprawdopodobniej wynika to z bardziej przychylnego podejścia urzędów z powiatu brzozowskiego do osób prowadzących działalność gospodarczą. Postawa urzędów w tym kontekście może wynikać z faktu dużego bezrobocia, które od wielu lat utrzymuje się w powiecie brzozowskim. Jedną z istotniejszych barier w obu powiatach okazał się brak własnego kapitału. Związane jest to z trudnościami jednostek gospodarczych w dostępie do kredytów bankowych. Ograniczeń związanych z wykorzystaniem kredytów można szukać zarówno po stronie podmiotów ubiegających się o kredyt, jak i po stronie banków. Analizując dane z tabeli, można dojść do wniosku, że lokalizacja działalności gospodarczej na terenie 
powiatu brzozowskiego może bardziej ograniczać jej rozwój niż lokalizacja w powiecie krośnieńskim. W opinii respondentów, bariery w postaci braku planów zagospodarowania przestrzennego, braku doświadczenia w prowadzeniu firmy, ograniczona wiedza z ekonomii, przedsiębiorczości oraz słaba jakość własnych produktów/usług okazały się najmniej istotne w prowadzeniu działalności gospodarczej.

Tabela 3. Bariery rozwoju przedsiębiorczości lokalnej w ocenie przedsiębiorców ${ }^{\star} \mathrm{z}$ powiatu krośnieńskiego i powiatu brzozowskiego w $2018 \mathrm{r}$.

\begin{tabular}{|c|l|c|c|}
\hline \multirow{2}{*}{ Lp. } & \multicolumn{1}{|c|}{ Nazwa bariery } & \multicolumn{2}{|c|}{ Średnia wartość oceny } \\
\cline { 3 - 4 } & & $\begin{array}{c}\text { powiat } \\
\text { krośnieński }\end{array}$ & $\begin{array}{c}\text { powiat } \\
\text { brzozowski }\end{array}$ \\
\hline 1. & Wysokie składki na ZUS & 4,75 & 4,45 \\
\hline 2. & Wysokie podatki lokalne & 4,05 & 3,30 \\
\hline 3. & Zbyt rozbudowany i skomplikowany system podatkowy & 4,05 & 3,70 \\
\hline 4. & $\begin{array}{l}\text { Brak działań promujących lokalną gospodarkę ze strony } \\
\text { lokalnych władz }\end{array}$ & 3,45 & 2,70 \\
\hline 5. & $\begin{array}{l}\text { Brak wsparcia informacyjnego w gminie na temat } \\
\text { warunków prowadzenia działalności gospodarczej }\end{array}$ & 3,00 & 1,85 \\
\hline 6. & $\begin{array}{l}\text { Trudności w uzyskaniu i załatwianiu spraw w lokalnych } \\
\text { urzędach }\end{array}$ & 3,00 & 1,95 \\
\hline 7. & Brak wykwalifikowanych pracowników & 2,80 & 2,95 \\
\hline 8. & Niska siła nabywcza mieszkańców & 2,30 & 2,05 \\
\hline 9. & Brak własnego kapitału & 2,25 & 2,60 \\
\hline 10. & $\begin{array}{l}\text { Konkurencja w postaci dużych zagranicznych koncernów/ } \\
\text { firm }\end{array}$ & 2,00 & 2,65 \\
\hline 11. & Niewystarczająca infrastruktura techniczna i transportowa & 1,85 & 1,25 \\
\hline 12. & Trudności ze znalezieniem bazy lokalowej & 1,70 & 1,55 \\
\hline 13. & Zła lokalizacja firmy & 1,15 & 2,05 \\
\hline 14. & Brak planów zagospodarowania przestrzennego & 1,15 & 0,90 \\
\hline 15. & $\begin{array}{l}\text { Brak doświadczenia w prowadzeniu firmy, ograniczona } \\
\text { wiedza z ekonomii, przedsiębiorczości }\end{array}$ & 0,90 & 1,35 \\
\hline 16. & Słaba jakość własnych produktów, usług & 0,35 & 1,90 \\
\hline & & & \\
\hline
\end{tabular}

* Skala przyjętych ocen: 0 - brak znaczenia, 5 - bardzo ważna bariera

Źródło: opracowanie własne na podstawie przeprowadzonych badań

\section{Podsumowanie}

Przedsiębiorczość lokalna z punktu widzenia rozwoju gospodarczego i podnoszenia poziomu życia mieszkańców powiatu krośnieńskiego i brzozowskiego ma kluczowe znaczenie. Mikroprzedsiębiorstwa, których w obu powiatach jest nieco ponad 95\%, napotykają szereg barier i ograniczeń w rozwoju. Zdaniem badanych przedsiębiorców, najważniejszymi czynnikami hamującymi rozwój przedsiębiorczości lokalnej są: zbyt wysokie składki ZUS, wysokie podatki lokalne oraz zbyt rozbudowany i skomplikowany system podatkowy. 
Jedną z istotniejszych barier rozwoju jest również brak wykwalifikowanych pracowników oraz brak działań promujących lokalną gospodarkę ze strony lokalnych władz. W związku z powyższym przyjęta w pracy hipoteza badawcza została zweryfikowana pozytywnie.

O dalszym rozwoju przedsiębiorczości lokalnej w powiecie krośnieńskim i brzozowskim będą decydować nie tylko indywidualne wysiłki przedsiębiorców, ale również polityka władz samorządowych oraz działania rządu na płaszczyźnie wsparcia finansowego, ograniczenia biurokracji i uproszczenia przepisów prawnych związanych z prowadzeniem działalności gospodarczej.

\section{Literatura}

References

Goszczyńska, M., Górnik-Durose, M. (red.). (2010). Psychologiczne uwarunkowania zachowań ekonomicznych. Warszawa: Difin.

GUS. (2018, 26 września). Bank Danych Lokalnych Głównego Urzędu Statystycznego. Pozyskano z: http://www.stat.gov.pl.

Kamińska, W. (2006). Pozarolnicza indywidualna działalność gospodarcza w Polsce w latach 1988-2003. Warszawa: Instytut Geografii i Przestrzennego Zagospodarowania PAN.

Krajewski, K., Śliwa, J. (2004). Lokalna przedsiębiorczość w Polsce. Uwarunkowania rozwoju. Warszawa: Wydawnictwo Naukowe Zarząazania Uniwersytetu Warszawskiego.

Makieła, Z. (2008). Przedsiębiorczość regionalna. Warszawa: Difin.

Michalczuk, G. (red.). (2009). Czynniki i narzędzia rozwoju MŚP. Białystok: Wydawnictwo Uniwersytetu w Białymstoku.

Ministerstwo Przedsiębiorczości i Technologii. (2018a, 18 października). Raport „Przedsiębiorczość w Polsce" 2017. Pozyskano z: https://www.mpit.gov.pl/strony/zadania/analiza-i-ocena-polskiej gospodarki/przedsiebiorczosc

Ministerstwo Przedsiębiorczości i Technologii. (2018b, 19 października). „Konstytucja biznesu” i inne zmiany prawne dla firm. Pozyskano z: https://www.mf.gov.pl/ministerstwo-finansow/wiadomosci/aktualnosci/-/asset_publisher/M1vU/content/id/5835923

Ministerstwo Rozwoju. (2018, 25 września). Pakiet 100 zmian dla firm. Pozyskano z: https://www.mf. gov.pl/documents/764034/5123672/100_zmian_dla_firm.pdf

Schumpeter, J. (1960). Teoria rozwoju gospodarczego. Warszawa: Wydawnictwo Naukowe PWN.

Strojny, J., Karaś, D., Kopeć, N. (2014). Zróżnicowanie przestrzenne potencjału przedsiębiorczego w województwie podkarpackim. Przedsiębiorczość - Edukacja, 10, 199-212.

Zioło, Z. (2007). Rola przedsiębiorczości w aktywizacji gospodarczej - zarys modelu. Przedsiębiorczość Edukacja, 3, 10-16.

Mateusz Suchodolski, mgr, Podkarpacka Szkoła Wyższa w Jaśle, Wydział Ekonomii, Gospodarki Przestrzennej i Transportu. Jego zainteresowania obejmują rozwój lokalny, przedsiębiorczość lokalną i turystykę.

Mateusz Suchodolski, MA, Podkarpacka Higher Education School in Jasło, Poland, Faculty of Economics, Spatial Management and Transport. His research interests include local development, local entrepreneurship, tourism.

ORCID: 0000-0002-7123-1231

\section{Adres/Address:}

Podkarpacka Szkoła Wyższa im. bł. ks. Władysława Findysza w Jaśle

ul. Na Kotlinę 8

38-200 Jasło, Polska

e-mail: suchodolski.mateusz@gmail.com 